\title{
Association of maternal serum vitamin D level with preeclampsia or eclampsia and its relationship with neonatal outcome and neonatal serum calcium level
}

\author{
Mahija Sahu, Sonali Tripathy*, Pallavi Bhuyan
}

Department of Obstetrics and Gynecology, SCB Medical College Hospital, Cuttack, Odisha, India

Received: 14 October 2017

Accepted: 08 November 2017

*Correspondence:

Dr. Sonali Tripathy,

E-mail: snltrpth87@gmail.com

Copyright: () the author(s), publisher and licensee Medip Academy. This is an open-access article distributed under the terms of the Creative Commons Attribution Non-Commercial License, which permits unrestricted non-commercial use, distribution, and reproduction in any medium, provided the original work is properly cited.

\section{ABSTRACT}

Background: Vitamin D deficiency has been associated with various poor maternal and fetal outcome and is proposed to be important in the pathogenesis of preeclampsia. The aim of the study was to evaluate the serum vitamin-D levels in normal pregnant females and pre-eclampsia or eclampsia individuals in the third trimester admitted for termination or in labour and to assess the neonatal outcome and neonatal serum calcium levels of babies born to mother in both the groups.

Methods: This study was a prospective comparative study carried out on the pregnant women in the third trimester admitted for termination or in labour. 100 pregnant females with either pre-eclampsia or eclampsia were compared with equal number of normotensive pregnant females for serum vitamin D. They were followed up until delivery and subsequently neonatal serum calcium level was estimated.

Results: Most pregnant females had vitamin D deficiency pointing towards universal prevalence. Only $10 \%$ had suboptimal to optimal vitamin D level while $90 \%$ had vitamin deficiency. The hypertensive group had lower mean serum vitamin D level $(9.06 \pm 5.20 \mathrm{ng} / \mathrm{ml})$ as compared to normotensive group $(13.67 \pm 7.24 \mathrm{ng} / \mathrm{ml})$. Neonatal outcome was poorer in the hypertensive group. Neonates born to hypertensive mothers had lower mean calcium level $(8.30 \pm 1.46 \mathrm{mg} / \mathrm{dl})$ when compared to those born to normotensive mothers $(8.82 \pm 0.918 \mathrm{mg} / \mathrm{dl})$.

Conclusion: The study findings revealed that there lies a consistent association of maternal serum vitamin D deficiency with the hypertensive disorders of pregnancy and neonatal morbidity.

Keywords: Calcium, Eclampsia, Neonatal, Preeclampsia, Vitamin D deficiency

\section{INTRODUCTION}

Vitamin D3, also known as calciferol, is a prohormone that plays an important role in calcium homeostasis and bone health in addition to its neuromuscular functions. ${ }^{1}$ Several studies reported the relationship between maternal Vitamin D deficiency and adverse maternal and fetal outcomes. ${ }^{2}$ In the last two decades, the non-classical function of Vitamin D has been suggested; it regulates a large number of human genes ( 200 genes), resulting in a wide range of autocrine effects in different tissues. ${ }^{3}$ For example, Vitamin D is involved in regulation of cell proliferation, cell differentiation, and apoptosis. ${ }^{4}$ It exerts immune responses through regulation of the innate and adaptive immunity. ${ }^{5}$ This explains the correlation of vitamin $\mathrm{D}$ deficiency to the potential risk of a series of conditions like hypertensive disorders, diabetes mellitus, cancer, multiple sclerosis, allergy, asthma, autoimmune and infectious diseases as well as depression. Hypertensive disorders of pregnancy are the most 
common medical complication of pregnancy and its association with vitamin D deficiency is worth discussing. Hypertensive disorders affect $7-15 \%$ of all gestations and account for potential maternal and perinatal risks and outcome. ${ }^{6}$ It includes gestational hypertension, preeclampsia, eclampsia, chronic hypertension, preeclampsia superimposed on chronic hypertension.

In India incidence of preeclampsia is $5-15 \%$, eclampsia is 1 in 500 to 1 in $30 .^{7}$ About $16 \%$ of maternal deaths were attributed to hypertensive disorders in developed countries and over half of these were preventable. ${ }^{8}$

Molecular data confronted with pathological studies directed towards a two-stage disorder. The key features in the pathogenesis of preeclampsia are abnormal trophoblastic invasion of spiral arteries, inappropriate endothelial cell activation and exaggerated inflammatory response. The known racial disparity in preeclampsia, with black women being more likely to develop severe preeclampsia than white women, suggests that Vitamin D may be relevant.

It has been suggested that preeclampsia and eclampsia results from breakdown of tolerance to the developing fetus after maternal immune maladaptation. ${ }^{9}$ Vitamin D is a seco-steroid prohormone which has direct effect on molecular pathways such as trophoblastic invasion and immunomodulation.

During pregnancy, Vitamin D may play a role in implantation and placental function due to angiogenic and anti-inflammatory effects. It is important in directing immune responses at the fetal-placental interface as well as immunological adaptation to reduce the risk of inflammation and infection.

Preeclampsia and eclampsia of varying degrees of severity form a considerable portion of admission in hospitals. Despite the considerable morbidity and mortality, the cause of preeclampsia and eclampsia has remained enigmatic.

It is thus necessary to identify the modifiable risk factors which will aid in primary prevention by avoiding the occurrence of the disease. Hence this study was undertaken to understand the association between serum Vitamin D level and development of preeclampsia or eclampsia and its correlation with neonatal outcome and neonatal serum calcium.

\section{METHODS}

This was a prospective comparative study which was conducted in the Department of Obstetrics and Gynaecology, SCB Medical College and Hospital, Cuttack. The pregnant females attending our OPD and labour room in third trimester of pregnancy for termination or in labour were considered. Initially 457 pregnant females were screened of which 350 patients were enrolled on the basis of inclusion and exclusion criteria. Some were lost to follow up and finally 200 pregnant females, 100 each from normotensive and hypertensive group either preeclampsia or eclampsia were studied. All the pregnant mothers who agreed to participate in this study gave their informed consent prior to their inclusion in the study. On admission, patient demographic profile, complete history was recorded, and comprehensive clinical examination was done. In all the patients, blood samples for routine examination along with LFT, RFT, random blood sugar, serum electrolytes, serum uric acid and serum vitamin D were drawn, and serum levels of these biochemical parameters were determined according to standard laboratory procedures. Serum vitamin D quantification was done by chemiluminescent assay. Those with diabetes mellitus, anemia, renal failure, hypothyroidism, multifetal gestation and immunosuppressive disorders were excluded from the study. Subjects were classified into four categories according to serum vitamin D level:

- $\quad>20 \mathrm{ng} / \mathrm{ml}$ : suboptimal to optimal

- $10-20 \mathrm{ng} / \mathrm{ml}$ : mild deficiency

- 5-10ng/ml: severe deficiency and

- $\quad<5 \mathrm{ng} / \mathrm{ml}$ : very severe deficiency.

All women were followed up until delivery and early postpartum period. Neonatal outcome in terms of maturity, complications and serum calcium was assessed. The results so obtained were tabulated. SPSS 21 software was used to analyse the data. Quantitative data was expressed as a mean \pm standard deviation. Categorical values were expressed as numbers (n) and percentages (\%). Data was analysed with a $95 \%$ confidence interval and a $\mathrm{p}$ value less than 0.05 was accepted as significant. Depending on the type of variables $\mathrm{p}$ value was derived using chi square, independent sample t-test and MannWhitney $U$ test. The correlation between maternal serum vitamin D and neonatal serum calcium level was analysed using Pearson product-moment correlation coefficient.

\section{RESULTS}

In this study of 200 patients, 100 patients each from normotensive and preeclampsia or eclampsia group were compared. The socio-demographic profile was analysed. No statistically significant differences were found in age $(p=0.792)$ and habituation between the two groups. The level of education $(\mathrm{p}=0.015)$ and socioeconomic status $(\mathrm{p}=0.023)$ was significantly lower in the preeclamptic and eclamptic group compared to the normotensive pregnant women. The preeclampsia and eclampsia group had either irregular or no ANC $(\mathrm{p}<0.001)$ (Table 1$)$.

There was universal prevalence of vitamin D deficiency among the pregnant females, but the level of serum vitamin D was significantly lower in the preeclamptic and eclamptic group. $75 \%$ of the patients in the hypertensive group with either preeclampsia or eclampsia were found 
to have very severe deficiency $(<5 \mathrm{ng} / \mathrm{ml})$ as compared to $25 \%$ of those in the healthy normotensive group. Among the 20 pregnant mothers (out of 200), with suboptimal to optimal (>20 ng/ml) serum vitamin D, only $6(30 \%)$ were from the hypertensive group and rest $14(70 \%)$ were from normotensive group. The mean serum vitamin $\mathrm{D}$ level was $9.06 \pm 5.20 \mathrm{ng} / \mathrm{ml}$ in diseased group compared to $13.67 \pm 7.24 \mathrm{ng} / \mathrm{ml}$ in healthy pregnant group which was statistically significant (Table 2).

Table 1: Comparison of sociodemographic profile between study (preeclampsia/eclampsia) and control group (normotensive).

\begin{tabular}{|c|c|c|c|c|}
\hline Variables & Preeclampsia and eclampsia group & Control group & Total & P-value* \\
\hline Age (years) & $23.42 \pm 3.36$ & $23.28 \pm 3.58$ & & $0.792^{\#}$ \\
\hline Booked & $16(18.8)$ & $69(81.2)$ & $85(42.5)$ & \multirow{3}{*}{$<0.001^{*}$} \\
\hline Irregular ANC & $58(75.3)$ & $19(24.7)$ & $77(38.5)$ & \\
\hline No ANC & $26(68.4)$ & $12(31.6)$ & $38(19.0)$ & \\
\hline \multicolumn{4}{|l|}{ Education } & \multirow{4}{*}{$0.015^{*}$} \\
\hline Illiterate & $37(66.1)$ & $19(33.9)$ & $56(28.0)$ & \\
\hline Up to high school & $56(44.8)$ & $69(55.2)$ & $125(62.5)$ & \\
\hline Above high school/graduate & $7(36.8)$ & $12(63.2)$ & $19(9.5)$ & \\
\hline \multicolumn{4}{|c|}{ Socioeconomic status } & \multirow{5}{*}{$0.023^{*}$} \\
\hline Lower & $22(55.0)$ & $18(45.0)$ & $40(20.0)$ & \\
\hline Lower middle & $33(66.0)$ & $17(34.0)$ & $50(25.0)$ & \\
\hline Upper lower/middle & $43(42.2)$ & $59(57.8)$ & $102(51.0)$ & \\
\hline Upper & $2(25.0)$ & $6(75.0)$ & $8(4.0)$ & \\
\hline
\end{tabular}

*Chi-Square test; \#independent sample t-test

Table 2: Comparison of maternal serum vitamin D (ng/ml) between study and control group.

\begin{tabular}{|lllll|}
\hline Vitamin D $(\mathrm{ng} / \mathrm{ml})$ & $\begin{array}{l}\text { Preeclampsia and } \\
\text { eclampsia group N }(\%)\end{array}$ & $\begin{array}{l}\text { Control group } \\
\mathbf{N}(\%)\end{array}$ & Total & P-Value \\
\hline$<5$ & $18(75.0)$ & $6(25.0)$ & $24(12.0)$ & \\
\hline $5-10$ & $59(65.6)$ & $31(34.4)$ & $90(45.0)$ & $<0.001^{*}$ \\
\hline $10-20$ & $17(25.8)$ & $49(74.2)$ & $66(33.0)$ & \\
\hline$>20$ & $6(30.0)$ & $14(70.0)$ & $20(10.0)$ & $<0.001^{\#}$ \\
\hline Mean \pm SD & $9.06 \pm 5.20$ & $13.67 \pm 7.24$ & & \\
\hline
\end{tabular}

*Chi-Square test; \#Mann-Whitney U test

Table 3: Comparison of neonatal outcome between study and control group.

\begin{tabular}{|c|c|c|c|c|}
\hline $\begin{array}{l}\text { Neonatal } \\
\text { outcomes }\end{array}$ & $\begin{array}{l}\text { Preeclampsia } \\
\text { and eclampsia } \\
\text { group } \mathbf{N}(\%)\end{array}$ & $\begin{array}{l}\text { Control } \\
\text { group } \\
\mathbf{N}(\%)\end{array}$ & Total & P-value \\
\hline \multicolumn{4}{|c|}{ Admission to SNCU } & \multirow{3}{*}{$<0.001 *$} \\
\hline No & $\begin{array}{l}62 \\
(42.2)\end{array}$ & $\begin{array}{l}85 \\
(57.8)\end{array}$ & $\begin{array}{l}147 \\
(73.5)\end{array}$ & \\
\hline Yes & $\begin{array}{l}38 \\
(71.7)\end{array}$ & $\begin{array}{l}15 \\
(28.3)\end{array}$ & $\begin{array}{l}53 \\
(26.5)\end{array}$ & \\
\hline
\end{tabular}

*Chi square test

Table 4: Comparison of mean birth weight $(\mathrm{kg})$ between study and control group.

\begin{tabular}{|llll}
$\begin{array}{lll}\text { Birth } \\
\text { weight }\end{array}$ & $\begin{array}{l}\text { Precclampsia } \\
\text { and eclampsia } \\
\text { group N }(\%)\end{array}$ & $\begin{array}{l}\text { Control } \\
\text { group }\end{array}$ & P- Value \\
Mean \pm SD & $2.22 \pm 0.42$ & $2.51 \pm 0.42$ & $<0.001^{\#}$ \\
\hline \#independent sample t-test & & \\
\hline
\end{tabular}

Table 5: Comparison of serum calcium level of babies born in study and control group.

\begin{tabular}{|c|c|c|c|c|}
\hline $\begin{array}{l}\text { Serum } \\
\text { calcium }\end{array}$ & $\begin{array}{l}\text { Preeclampsi } \\
\text { and } \\
\text { eclampsia } \\
\text { group N } \\
(\%)\end{array}$ & $\begin{array}{l}\text { Control } \\
\text { group } \\
\mathbf{N}(\%)\end{array}$ & Total & $\begin{array}{l}\text { P- } \\
\text { Value }\end{array}$ \\
\hline $\begin{array}{l}\text { Normal } \\
\text { calcium }\end{array}$ & $\begin{array}{l}52 \\
(43.7)\end{array}$ & $\begin{array}{l}67 \\
(56.3)\end{array}$ & $\begin{array}{l}119 \\
(59.5)\end{array}$ & \\
\hline $\begin{array}{l}\text { Calcium } \\
\text { deficient }\end{array}$ & $\begin{array}{l}48 \\
(59.3)\end{array}$ & $\begin{array}{l}33 \\
(40.7)\end{array}$ & $\begin{array}{l}81 \\
(40.5)\end{array}$ & $0.031 *$ \\
\hline Mean \pm SD & $8.30 \pm 1.46$ & $8.82 \pm 0.92$ & & $0.003^{\#}$ \\
\hline
\end{tabular}

*Chi square test; \#independent sample t-test

In the preeclampsia and eclampsia group most babies had preterm birth and almost 62 out of 100 required SNCU admission due to prematurity or other neonatal complications like growth restriction, respiratory distress, meconium aspiration syndrome or hypoxic ischemic encephalopathy. The difference in the two groups in 
terms of neonatal SNCU admission was statistically significant (Table 3). The mean birth weight of the newborn in the hypertensive group $(2.22 \pm 0.42 \mathrm{~kg})$ was lower as compared to normotensive group $(2.51 \pm 0.42 \mathrm{~kg})$ with $\mathrm{p}$ value $<0.001$ (Table 4$)$. Out of the 81 newborn babies with calcium deficiency $(<8 \mathrm{mg} / \mathrm{dl}), 48(59.3 \%)$ were from hypertensive (preeclampsia or eclampsia) group and $33(40.7 \%)$ were from normotensive group. The mean neonatal serum calcium in the hypertensive group was $8.30 \pm 1.46 \mathrm{mg} / \mathrm{dl}$ as compared to $8.82 \pm 0.92 \mathrm{mg} / \mathrm{dl}$ in the healthy pregnant group which was statistically significant (Table 5). The calcium deficient state may be because of the preterm and low birth weight babies. Neonatal serum calcium deficiency was more prevalent in the babies born to pregnant mothers with severe $(5-10 \mathrm{ng} / \mathrm{ml})$ and very severe $(<5 \mathrm{ng} / \mathrm{ml})$ serum vitamin $\mathrm{D}$ deficiency (Table 6$)$.

Table 6: Correlation of maternal serum vitamin D level with neonatal serum calcium level.

\begin{tabular}{|lllllll|}
\hline & \multicolumn{2}{l}{ Serum Vitamin D level } & \multicolumn{3}{c}{ Total } & P value \\
\hline Calcium & $\mathbf{5}$ & $\mathbf{5 - 1 0}$ & $\mathbf{1 0 - 2 0}$ & $\mathbf{> 2 0}$ & & \\
\hline Normal calcium & $3(2.5)$ & $38(31.9)$ & $59(49.6)$ & $19(16.0)$ & $119(59.5)$ & $<0.001^{*}$ \\
\hline Calcium deficient & $21(25.9)$ & $52(64.2)$ & $7(8.6)$ & $1(1.2)$ & $81(40.5)$ & \\
\hline
\end{tabular}

*Chi-Square test

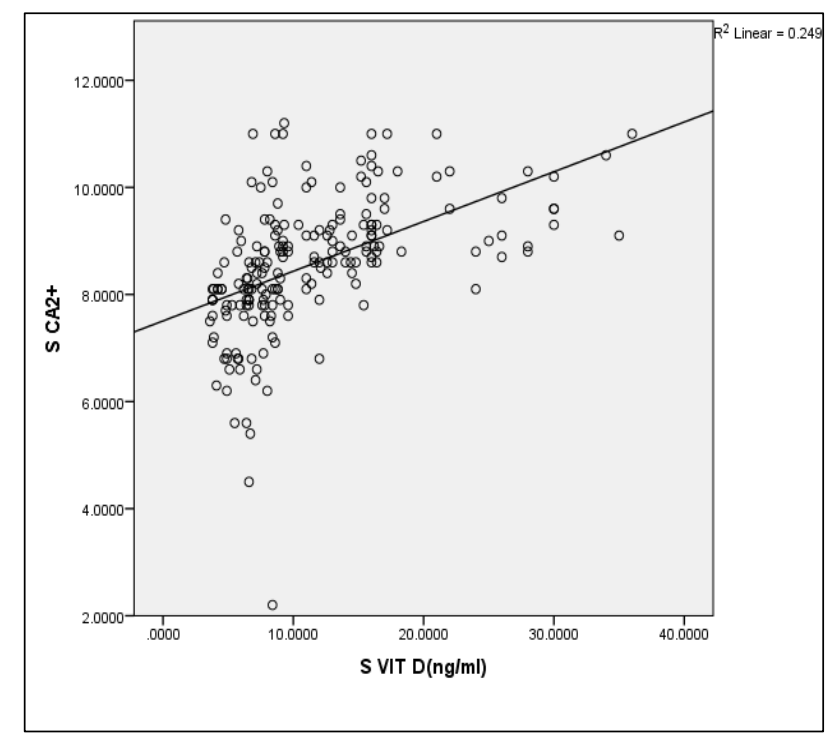

Figure 1: Pearson correlation between maternal serum vitamin $D$ and neonatal serum calcium.

Pearson correlation between maternal serum vitamin D and neonatal serum calcium level showed a significant positive correlation with $r=0.652$ and $p<0.001$. It means as the serum vitamin $\mathrm{D}$ level increases the serum calcium level also increases linearly and this increase here is statistically significant (Figure 1).

\section{DISCUSSION}

Vitamin D insufficiency has been associated with a number of adverse health outcomes such as gestational diabetes, hypertensive disorders, risk of infections, caesarean section and fetal growth restriction. Literature on this topic is growing rapidly.

Vitamin D is a pro hormone derivative from cholesterol. It has two origins: Endogenous and exogenous. During endogenous synthesis, 7-dehydrocholesterol in the deep layers of the skin under the effect of ultraviolet UVB (290-315 nm) forms previtamin D which undergoes thermal isomerization to form cholecalciferol. Then in the liver it is hydroxylated to 25-hydroxy derivative, calcidiol. This is released into circulation bound to a vitamin D binding globulin, which is the main storage form. In kidney, the calcidiol undergoes either 1hydroxylation to yield active metabolite, 1,25-dihydroxyvitamin D (calcitriol), or 24-hydroxylation to yield a probably inactive metabolite.

Calcitriol exerts the hormonal action via binding to nuclear vitamin D receptors, which are present throughout the body, including pregnancy-specific tissues such as the placenta and uterine placental bed (decidua). During pregnancy, vitamin D may play a role in implantation and placental function potentially due to angiogenic, immunomodulatory, and anti-inflammatory effects.

Vitamin D is considered as having a major role in the synthesis and regulation of genes that are effective in the early developmental phase of the placenta. ${ }^{10,11}$ Placental abnormalities associated with preeclampsia occur before the remodeling in the vascular structures. ${ }^{12,13}$

Immunomodulatory properties of vitamin $\mathrm{D}$ have been reported to play a key role in the development of immunological tolerance in pregnancy and the presence of a sufficient level of vitamin D has been emphasized to have a role in the management and prevention of $\mathrm{PE} .^{14}$

Low vitamin D levels has been associated with increased IL-6 concentrations through stress induced kinase, p38 inactivation, and inhibition of inflammatory cytokines of tumor necrosis factor alpha. ${ }^{15,16}$ Moreover, vitamin D play a major role in the endothelial cell function and dysfunction in cell culture models by modulating endothelial progenitor cells. ${ }^{17}$ The placental growth factor (PIGF) was detected to be significantly decreased. Vitamin D has been thought to play a potent endocrine 
suppressor role in renin biosynthesis for the regulation of the renin-angiotensin system. In addition, hypertension is suggested to be tied to preeclampsia and eclampsia.

Various studies have shown the relationship between preeclampsia and vitamin $\mathrm{D}$ to be complicated. They have shown a low vitamin D level in the second trimester to be an indicator of preeclampsia. ${ }^{18-21}$ When defining the level of vitamin D in the serum, though not standard, the cut-off level for vitamin D deficiency is acceptable at 20 $\mathrm{ng} / \mathrm{ml}$ in the latest studies, although previously it was accepted at $15 \mathrm{ng} / \mathrm{ml}^{22,23}$

In the present study although serum vitamin D deficiency was invariably present in both the groups, it was more severe in the mothers with preeclampsia and eclampsia. Robinson et al carried out a study to assess the levels of total 25-hydroxyvitamin D (25-OH-D) at diagnosis of early-onset severe preeclampsia and found reduced total 25-OH-D levels in comparison to healthy controls ( $\mathrm{P}$ <0.01). ${ }^{24}$ In another case control study, Bodnar et al determined the association between maternal vitamin D status at $\leq 26$ weeks of gestation and the risk of preeclampsia. $^{25}$ At delivery maternal 25-OH-D concentrations remained $15 \%$ lower in women with overt preeclampsia compared with non-preeclamptic. This was consistent with our results.

Hypponen et al did a systematic review and meta-analysis and concluded that low maternal serum 25(OH)D levels lead to an increased risk of preeclampsia whereas vitamin D supplementation lowered this risk. ${ }^{26}$ Bakacak $M$ et al also found similar results. ${ }^{27}$

Further supporting our results, Gupta et al estimated serum vitamin $\mathrm{D}$ level in term normotensive and preeclamptic. ${ }^{28}$ All the patients enrolled in both the study and control group were found to be vitamin D deficient. They found more incidence of severe vitamin D deficiency $(90 \%)$ in preeclamptic patients as compared to normotensive patients $(62 \%)$. This difference in the median maternal vitamin D levels of both the groups was found to be statistically significant.

Contrary to that Canadian researchers Baker AM et al did a nested case control study and found no association between 25-OH-D and preeclampsia at 16-18 weeks. $^{29}$ Wetta et al and Gidlof $\mathrm{S}$ et al in their case control study, measured mid gestational serum vitamin D level in the two groups and found no statistical difference..$^{30,31}$

Babies of preeclampsia mothers were calcium deficient which may be because of the prematurity and low birth weight. $36 \%$ of the preeclampsia and eclampsia group mothers had preterm babies and $18 \%$ in the control group were preterm. $38 \%$ were admitted to SNCU as compared to control group with $15 \%$ admission. This revealed a significant association of SNCU admission with disease $(\mathrm{p}<0.001)$.
This is supported by Morgan et al who showed $62.5 \%$ admission in his study group. ${ }^{32}$ The diseased group were more prone to develop neonatal complications which was supported by Abramovici et al. ${ }^{33}$

Out of the 24 babies born to very severe vitamin D deficient mothers, 14 (58.3\%) were low birth weight $(<2.5 \mathrm{~kg})$ which is in line with what has been mentioned in earlier literature that there is a higher incidence of low birth weight neonates in vitamin $\mathrm{D}$ deficient mothers.

Calcium deficiency $(<8.4 \mathrm{mg} / \mathrm{dl})$ in the neonates was $64.2 \%$ and $25.9 \%$ with serum vitamin D 5-10 and $<5$ $\mathrm{ng} / \mathrm{ml}$ respectively. The $\mathrm{p}$ value as per chi square test was statistically significant. Pearson correlation between serum vitamin $\mathrm{D}$ and neonatal calcium level showed a significant positive correlation with $r=0.652$ and $p$ value $<0.001$.

In a 2-year retrospective study by Taema $\mathrm{FH}$ et al, all newborns presenting to the pediatric emergency centers with symptomatic hypocalcemia were admitted and their maternal serum vitamin D level was estimated. ${ }^{34}$ They found a positive association between the two.

This was supported by Mehrotra et al who evaluated association of maternal hypo-vitaminosis with neonatal hypocalcemia. $^{35}$ They included 60 infants with hypocalcemic seizures and their mothers (study group) and 60 healthy breastfed infants with their lactating mothers (control group). High prevalence of hypovitaminosis $\mathrm{D}(<10 \mathrm{ng} / \mathrm{mL})$ was observed in study mothers $(85 \%)$. Zeqhoud et al showed that administration of a single low dose of vitamin D3 (100,000 I.U.) on the sixth or seventh month of pregnancy allowed to prevent neonatal hypocalcemia. ${ }^{36}$

\section{CONCLUSION}

Present study establishes a consistent association of maternal serum vitamin D deficiency with hypertensive disorders, preeclampsia and eclampsia. This study has raised the intriguing possibility of association of maternal serum vitamin D deficiency with that of neonatal calcium deficiency and poor neonatal outcome.

The present study serves as a need for larger randomized controlled studies and meta analyses to confirm the findings. It is suggested that those in the risk group of vitamin $\mathrm{D}$ deficiency can be prevented from having hypertensive disorders in pregnancy through a simple step of vitamin D supplementation during pregnancy.

\section{ACKNOWLEDGMENTS}

Authors are immensely grateful to the Department of Obstetrics and Gynecology, SCBMCH Cuttack for the support. Authord also extend their gratitude to the Department of Biochemistry and Pathology of their institute. 
Funding: No funding sources

Conflict of interest: None declared

Ethical approval: The study was approved by the Institutional Ethics Committee

\section{REFERENCES}

1. Kulie T, Groff A, Redmer J, Hounshell J, Schrager S. Vitamin D: an evidence-based review. J Am Board Fam Med. 2009;22(6):698-706.

2. Thacher TD, Clarke BL. Vitamin D insufficiency. Mayo Clin Proc. 2011;86:50-60.

3. Cannell JJ, Hollis BW. Use of vitamin D in clinical practice. Altern Med Review. 2008;13:6-20.

4. Gallagher JC, Sai AJ. Vitamin D insufficiency, deficiency, and bone health. J Clin Endocrinol Metab. 2010;95:2630-3.

5. Adams JS, Hewison M. Unexpected actions of vitamin D: new perspectives on the regulation of innate and adaptive immunity. Nat Clin Pract Endocrinol Metab. 2008;4:80-90.

6. James, Rachael P, Piercy CN. Management of hypertension before, during and after pregnancy. Heart. 2004;90(12):1499-504.

7. Dutta DC. Text Book of obstetrics, hypertensive disorders of pregnancy. $7^{\text {th }} \mathrm{Edn} ; 2014: 220,230$.

8. Cunningham FG, Leveno KJ, Bloom SL, Spong CY, Dashe JS, Hoffman BL, et al. Hypertensive disorders. Williams Obstetrics. $24^{\text {th }}$ edition. McGraw-Hill Eductaion; 2014:728-9.

9. Robertson SA, Bromfield JJ, Tremellen KP. Seminal priming for protection from preeclampsia-a unifying hypothesis. J Reprod Immunol. 2003;59:253-65.

10. Fischer D, Schroer A, Ludders D, Cordes T, Bücker B, Reichrath J, et al. Metabolism of vitamin D3 in the placental tissue of normal and preeclampsia complicated pregnancies and premature births. Clin Exp Obstet Gynecol. 2007;34:80-4.

11. Novakovic B, Sibson M, Ng HK, Manuelpillai U, Rakyan V, Down T, et al. Placenta-specific methylation of the vitamin D 24-hydroxylase gene: implications for feedback autoregulation of active vitamin D levels at the fetomaternal interface. J Biol Chem. 2009;284:14838-48.

12. Huppertz B. Placental origins of preeclampsia challenging the current hypothesis. Hypertension 2008;51:970-75.

13. Ullah MI, Koch CA, Tamanna S, Rouf S, Shamsuddin L. Vitamin D deficiency and the risk of preeclampsia and eclampsia in Bangladesh. Horm Metab Res. 2013;45:682-7.

14. Wamberg L, Cullberg KB, Rejnmark L, Richelsen B, Pedersen SB. Investigations of the anti-inflammatory Effects of Vitamin D in Adipose tissue: results from an in vitro study and a randomized controlled trial. Horm Metab Res. 2013;45:456-62.

15. Nonn L, Peng L, Feldman D, Peehl DM. Inhibition of p38 by vitamin D reduces interleukin-6 production in normal prostate cells via mitogen activated protein kinase phosphatase 5: implications for prostate cancer prevention by vitamin D. Cancer Res. 2006;66(8):4516-24.

16. Bednarek-Skublewska A, Smolen A, Jaroszynski A, Załuska W, Ksiazek A. Effects of vitamin D3 on selected biochemical parameters of nutritional status, inflammation, and cardiovascular disease in patients undergoing long-term hemodialysis. Pol Arch Med Wewn. 2010;120:167-74.

17. Ertek S, Akgül E, Cicero AF, Kütük U, Demirtaş S, Cehreli S, et al. 25-Hydroxy Vitamin D levels and endothelial vasodilator function in normotensive women. Arch Med Sci. 2012;8:47-52.

18. Powe CE, Seely EW, Rana S, Bhan I, Ecker J, Karumanchi SA, et al. First trimester vitamin D, vitamin $\mathrm{D}$ binding protein, and subsequent preeclampsia. Hypertension. 2010;56:758-63.

19. Bodnar LM, Catov JM, Simhan HN, Holick MF, Powers RW, Roberts JM. Maternal vitamin D deficiency increases the risk of preeclampsia. J Clin Endocrinol Metab. 2007;92:3517-22.

20. Wei SQ, Audibert F, Luo ZC, Nuyt AM, Masse B, Julien P, et al. MIROS study group. Maternal plasma 25-hydroxyvitamin D levels, angiogenic factors, and preeclampsia. Am J Obstet Gynecol. 2013;208:390e1.

21. Haugen M, Brantsaeter AL, Trogstad L, Alexander J, Roth C, Magnus P, et al. Vitamin D supplementation and reduced risk of preeclampsia in nulliparous women. Epidemiol. 2009;20:720-6.

22. Holick MF, Binkley NC, Bischoff-Ferrari HA, Gordon CM, Hanley DA, Heaney RP, et al. Endocrine Society. Evaluation, treatment, and prevention of vitamin D deficiency: an Endocrine Society clinical practice guideline. J Clin Endocrinol Metab. 2011;96:1911-30.

23. Singla R, Gurung P, Aggarwal N, Dutta U, Kochhar R. Relationship between preeclampsia and vitamin D deficiency: a case control study. Arch Gynecol Obstet. 2015;291:1247-51.

24. Robinson CJ, Alanis MC, Wagner CL. Plasma 25hydroxyvitamin D Levels in early-onset severe preeclampsia. Am J Obstet Gynecol. 2010;203:366.

25. Bodnar LM, Simhan HN, Catov JM. Maternal Vitamin D status and the risk of mild and severe preeclampsia. Epidemiol. 2014;25:207-14.

26. Hypponen E, Cavadino A, Williams D. Vitamin D and pre-eclampsia original data, systematic review and meta-analysis. Ann Nutr Metab.2014;63:331-40.

27. Bakacak M, Serin S, Ercan O. Comparison of Vitamin D levels in cases with preeclampsia, eclampsia and healthy pregnant women. Int J Clin Exp Med. 2015;8:16280-6.

28. Gupta T, Wahi S, Gupta N, Arora S, Gupta S, Bhatia P. Correlation of Vitamin D levels in term normotensive and pre-eclamptic patients in labor. $\mathbf{J}$ Obstet Gynecol India. 2015;42(3):1-6.

29. Baker AM, Haeri S, Camargo CA, Stuebe AM, Boggess KA. A nested case-control study of firsttrimester maternal vitamin $\mathrm{d}$ status and risk for 
spontaneous preterm birth. Am J Perinatol. 2011;28(9):667-72.

30. Wetta LA, Biggio JR, Cliver S, Abramovici A, Barnes S, Tita AT. Is midtrimester vitamin D Status associated with spontaneous preterm birth and preeclampsia? Am J Perinatol. 2014;31:541-6.

31. Gidlof S, Silva AT, Gustafsson S, Lindqvist PG. Vitamin D and the risk of preeclampsia-a nested case-control study. Acta Obstetricia et Gynecologica Scandinavica. 2015;94(8):904-8.

32. Hall DR, Odendaal HJ, Kirsten GF, Smith J, Grové D. Expectant management of early onset, severe Preeclampsia perinatal outcome. BJOG. 2001;108:1258-64.

33. Abramovici D, Friedman SA, Sibai BM. Neonatal outcome in severe Preeclampsia at 24 to 36 weeks gestation: Does the HELLP syndrome matter? Am J Obstet Gynecol. 1999;180:220-5.

34. Teaema FH, Al Ansari K. Nineteen cases of symptomatic neonatal hypocalcemia secondary to vitamin D deficiency: a 2-year study. J Trop Pediatr. 2010;56:108-10.

35. Mehrotra P, Marwaha RK, Aneja S. Hypovitaminosis D and hypocalcemic seizures in infancy. Indian Pediatr. 2010;47:581-6.

36. Zeghoud F, Garabedian M, Jardel A, Bernard N, Melchior J. Administration of a single dose of 100,000 U.I. of vitamin D3 in the pregnant woman in winter. The effect on blood calcium level of the newborn infant. J Gynecol S Obstet Biol Reprod. 1988; 17:1099-105.

Cite this article as: Sahu M, Tripathy S, Bhuyan P. Association of maternal serum vitamin D level with preeclampsia or eclampsia and its relationship with neonatal outcome and neonatal serum calcium level. Int J Reprod Contracept Obstet Gynecol 2017;6:5580-6. 